\title{
İş Güvenliği Uzmanlığı Bilirkişileri Üzerine Bir Çalışma ${ }^{1}$
}

\section{A Study on Occupational Safety Expert Witnesses}

\author{
Onur DOĞAN* \\ (iD) 0000-0001-8231-9872
}

\author{
Ahmet Mahmut KILIÇ*** \\ (iD) 0000-0002-2082-749X
}

\section{ÖZ}

İş güvenliği uzmanlarının temel amacı çalışma alanlarında meydana gelebilecek olası kaza risklerini önlemek ve bu risklere yönelik gerekli tedbirleri almaktır. Tedbirler alınmaya çalışılsa da değişik nedenlerden dolayı çalışma hayatında iş kazaları yaşanmaya devam etmektedir. İş kazası sonrası, kazalar bazı durumlarda kazaya maruz kalan birey ya da yakınları tarafindan; bazı durumlarda ise işveren tarafından yargıya taşınmaktadır. Bunun dışında kazaya maruz kalan taraf ya da işverenlerin talebi olmaksızın kazanın ciddiyetine göre adli makamlarca kamu adına da resen sorușturma açılmakta ve konu yargıya taşınmaktadır. $\mathrm{Bu}$ kapsamda iş kazalarını önleme aşamasında görev alan iş güvenliği uzmanları, yargıya taşınmış iş kazaları dosyalarında hâkimin özel ve teknik bilgisine başvurduğu uzman bilirkişiler olarak görev yapmaktadır. Bu çerçevede Türkiye'de iş kazaları ile ilgili Bölge Adliye Mahkemeleri'ne bağlı olarak görev yapan iş güvenliği uzmanlığı bilirkişiler arasında yapılan bu araştırma tarama modeli ile yapılan betimleyici bir çalışma olup; araştırma örneklemini oluşturan 65 iş güvenliği uzmanlığı bilirkişinin yaklaşık olarak yarısının $(\% 47,7)$ bir yıllık süre zarfinda (2018 yılında) 20 ve üzeri sayıda bilirkişsilik dosyasında görev aldığı, yine büyük çoğunluğunun $(\% 81,5)$ düzenledikleri bilirkişi raporu ile mahkemelerin aynı yönde karar verdiği, araştırma kapsamındaki bilirkișilerin uygulamaları sırasında \%63,1'inin mahkeme boyutunda (bilirkişilik ücretinin düşük takdir edilmesi), \%18,4'ünün taraflar boyutunda (tarafların bilirkişiye yalan söylemesi/manipüle etmesi), \%53,8'inin bilirkişi komisyonu boyutunda (alanında uzman olmayan kişilerin görevlendirilmesi) sorunlar yaşadığı belirlenmiștir.

Anahtar Sözcükler: İş güvenliği, iş kazaları, bilirkişilik, bilirkişilik müessesesi
Sosyal Güvenlik Dergisi / Journal of Social Security Cilt: 10 Say1: 1 Y1l: 2020 / Volume: 10 Issue: 1 Year: 2020

ayfa Aralı̆̆ı: 165-184 Pages: 165-184

OI: 10.32331/ sgd.753083

Önerilen atıf şekli: Doğan, O. ve Kılıç, A. M. (2020). İș Güvenliği Uzmanlığı Bilirkişileri Üzerine Bir Çalıșma.

Sosyal Güvenlik Dergisi (Journal of Social Security). 10(1). 165-184.

Geliş Tarihi/Received: 03/05/2019 • Güncelleme Tarihi/Revised: 22/01/2020 • Kabul Tarihi/Accepted: 16/06/2020

\footnotetext{
* Öğr. Gör., Gümüşhane Üniversitesi, Gümüşhane Meslek Yüksekokulu, İş Sağlığı ve Güvenliği Programı, onurdogan@gumushane.edu.tr

** Prof. Dr., Çukurova Üniversitesi, Mühendislik ve Mimarlık Fakültesi, Maden Mühendisliği Bölümü, kilicm@cu.edu.tr

${ }^{1} \mathrm{Bu}$ makale 4. Uluslararası İş Güvenliği ve Çalışan Sağlığı Kongresinde (12-13 Nisan 2019) sözel olarak sunulmuştur.
} 


\section{GİRIŞ}

Sanayileşmenin ortaya çıkmasıyla, küresel pazarda yerini almak isteyen ülkeler daha fazla hammadde arayışına girişmişlerdir. Sanayi devrimi ile buharlı makinelerin icat edilmesi ve hızla gelişen makineleşme, hammaddeye olan ihtiyacı da arttırmıştır. Yeni makinaların icat edilmesi ve kurulan fabrikaların sayısındaki artış hem madde temininde hem de sanayi alanında çalışan işçi sayısında artışa neden olmuştur. Bu gelişmeler bir taraftan istihdam oranını arttırırken diğer taraftan çalışanların sağlığı ve güvenliği ile ilgili birçok sorunun da ortaya çıkmasına neden olmuştur. Çalışanların işverenlerden daha insancıl şartlarda çalışma ve çalışma sürelerini iyileştirici bazı haklar talep etmeye başlaması, iş̧̧i sınıfı içerisinde kolektif bir bilincin oluşmasını sağlamış bu ise işçi hakları konusunda işveren ve işvereni denetleyici mekanizma olan devletleri düzenlemeler yapmakta zorunlu kılmıştır.

Günümüzde insanoğlu üretimin ve tüketimin olduğu birçok alanda farklı tehlikelere maruz kalabilmektedir. $\mathrm{Bu}$ nedenle iş yaşamında çalışma ortamının risklerini minimize edecek düzenlemeler yapılmaktadır. Çoğunlukla kamu idaresi tarafından yapılan bu düzenlemeler, işverenlere, kurumlara ve çalışanlara belirli sorumluluklar yüklemektedir. Buna rağmen iş ortamında yapılan hatalar ve yaşanan ihmallerden dolayı birçok işçi yaralanmakta hatta yaşamını kaybedebilmektedir. İş sağlığı ve güvenliği alanında işverene, çalışanlara ve kurumlara çeşitli sorumluluklar yükleyen hukuki düzenlemeler, olası ihmaller ve hataların yaşanmış olma ihtimaline karşı kimi zaman tarafların şikâyeti kimi zaman ise tarafların şikâyetine gerek duyulmaksızın resen yargı sürecine taşınmaktadır. Yargılama sürecinde ise yaşanan iş kazaları ile ilgili adli makamlar tarafından alanında özel ve teknik bilgiye sahip uzman kişiler bilirkişi olarak görevlendirilmekte ve yaşanan iş kazasının yargılama sürecinde adli makamlara yardım etmesi beklenmektedir.

Bu kapsamda Türkiye'de iş sağlığı ve güvenliği alanında yarg1 sürecine taşınan ve yargılamaların yapıldığı vakalarda bilirkişi olarak görev alan iş güvenliği uzmanlarını konu alan bu araştırma, Bölge Adliye Mahkemeleri bünyesindeki Bölge Bilirkişilik Kurullarına kayıtlı olan ve kayıtlı olmayan iş güvenliği uzmanlığı bilirkişiler üzerine yapılmıştır. Bilirkişilik müessesesi, iş kazalarının adli makamlarca çözüme kavuşturulabilmesi için özel ve teknik bilgisine başvurulan bir müessesedir. İş güvenliği uzmanı bilirkişiler, yargıya taşınan iş kazaları ile ilgili olarak yargılama makamlarınca görevlendirilerek, söz konusu iş kazası hakkında çoğunlukla kusur oranlarını, kazanın meydana gelmesine etki eden tüm süreçleri dikkate alırlar. Olaylar arasında sebep sonuç ilişkisi kurarak iş güvenliği alanında mevcut yönergeler ve talimatlar 1şığında uygulamadan doğan eksiklikleri tespit ederler. Bu tespitler ve değerlendirmeler işveren ve işçi açısından yapılan değerlendirmeleri ve kazaya sebebiyet veren olası ihmalleri derinlemesine araştıran ve çalışma alanın da keşfine dayanan bir raporu içermektedir. İş güvenliği uzmanlığ 1 bilirkişileri tarafından hazırlanan bilirkişi raporları, yargılama süreçlerinde hâkim tarafından verilecek karara bizzat gerekçe oluşturabileceği gibi gelecekte yaşanması muhtemel benzeri kazaların önüne geçmek için de kanun koyuculara kaynak oluşturabilmektedir. Bu kapsamda yapılan bu araştırma, iş kazalarında mahkemeler tarafından görevlendirilen iş güvenliğgi uzmanlığ 1 bilirkişilerin, bilirkişilik görevlerinde yaşadıkları sorunlar üzerine tespitleri konu alan betimleyici bir araştırmadır. 


\section{I- İS SAĞLIĞI VE GÜVENLİĞİ KAVRAMI}

İş sağlı̆̆ı; çalışanların iş ortamında maruz kaldıkları ve sağlıklarını etkileyen riskler karşısında koruyucu önlem veya kuralları içeren düzenlemelerdir (Bıyıkc1, 2010: 6). İş kazaları ve meslek hastalıklarından kaynaklı yaşanabilecek kayıpları en aza indirmek için bilimsel araştırmalara dayalı güvenlik önlemlerinin belirlenmesi ve uygulanması yönündeki çalışmalar ise "iş güvenliği”" olarak tanımlanmaktadır. İş güvenliğinin başlıca üç temel amacı bulunmaktadır. Bunlar; çalışanların güvenliğini, üretim güvenliğini ve işletme güvenliğini sağlamaktır (Selek, 2016: 25). İş güvenliğinin öncelikli temel amacı çalışan güvenliğini sağlamaktır. Çünkü çalışanlar hammaddenin elde edilmesinden nihai ürüne dönüşümüne kadar geçen süreçte; üretim, çalışma ortamı, dış etkenler gibi birçok faktörden etkilenebilmekte ve bazı tehlikelere maruz kalabilmektedir. Üretim güvenliği, hammaddenin nihai ürüne dönüşümünü sağlamaktan kullanıma hazır hale getirilene kadar geçen süreçte çalışan ve çevre için herhangi bir tehlike yaratmayacak şekilde sunulması veya muhafaza edilmesidir. İşletme güvenliği ise kullanılan yöntem ve tekniklerin işletme, çalışan üretim ve çevre için herhangi bir tehlike oluşturmayacak şekilde alınması gereken önlemler olarak tanımlanabilir. Genel itibariyle iş sağlığı ve güvenliğinin amacı iş ortamından kaynaklanabilecek iş kazaları ve meslek hastalıklarından çalışanları korumak ve çalışanlara daha güvenli bir çalışma ortamı sunmaktır.

\section{A- İş Kazaları}

2006 tarihli 5510 sayılı Sosyal Sigortalar ve Genel Sağlık Sigortası Kanunu'nun 13. md.'sinde “İş kazası; "İ̧sveren tarafindan yürütülmekte olan iş nedeniyle sigortalı kendi adına ve hesabına bağımsız çalışlyorsa yürütmekte olduğu iş nedeniyle, bir işverene bağh olarak çalışan sigortalının, görevli olarak işyeri dışında başka bir yere gönderilmesi nedeniyle asıl işini yapmaksızın geçen zamanlarda, bu Kanunun 4.md. 'sinin birinci fikrasının (a) bendi kapsamındaki emziren kadın sigortalının, iş mevzuatı gereğince çocuğuna süt vermek için ayrılan zamanlarda, Sigortalıların, işverence sağlanan bir taşıtla işin yapıldı̆̆ yere gidiş gelişi sırasinda, meydana gelen ve sigortaliyı hemen veya sonradan bedenen ya da ruhen engelli hâle getiren olaydır."

2012 tarihli ve 6331 sayılı İş Sağlığı ve Güvenliği Kanunu'nun 3. md.'sinde ise iş kazası “iş yerinde veya işin yürütümü nedeniyle meydana gelen, ölüme sebebiyet veren veya vücut bütünlüğünü ruhen ya da bedenen engelli hâle getiren olay" olarak tanımlanmıştır. Uluslararası Çalışma Örgütü (ILO)'ne göre iş kazası; belirli bir zarara veya yaralanmaya neden olan beklenmeyen ve daha öncesinde planlanmamış olay olarak tanımlanmıştır (ILO,1993). Dünya Sağlık Örgütü (WHO)'ne göre iş kazası; daha önceden planlanmamış çoğu kez kişisel yaralanmalara, makine ve araç gereçlerin zarara uğraması ve üretimin durmasına neden olan olay olarak tanımlanmıştır (WHO, 1995: 7-8).

Türkiye'de ve dünyada hemen hemen her gün pek çok kaza olmaktadır. Bu kazaların birçoğu yaralanmalıdır. Bazıları ise ölüm ile sonuçlanmaktadır. İş kazalarının başlıca sebepleri; makine, insan ve çevredir. İş kazalarının \%81'i insan hatasından kaynaklanırken \%17'si çalışma ortamından \%2'si ise engellenmesi mümkün olmayan doğal afetlerden kaynaklanmaktadır (Bıyıkcı, 2010: 3). İş kazaları ve meslek hastalıkları çok faktörlü bir sorun olup değişkenlik gösterebilen bir sorundur. Çalışma ortamından veya işin yapısından kaynaklı iş kazaları, alınacak önlemler ve gelişmiş uygulamalar ile tehlikeler veya olası riskler en aza indirebilir. Mühendislik ve idari önlemler, risk analizleri, ikame, bakım onarım, bilgilendirme, eğitim, işin tehlike sınıfı ve mevzuatın gerektirdiği süre göz önünde bulundurularak işçilerin periyodik sağlık kontrollerinin yapılması, kişisel koruyucu donanım 
temini vb. düzenlemeler çalışanların meslek hastalıklarına ve iş kazalarına karşı engelleyici veya önleyici unsurlar olarak siralanabilir.

İş sağlı̆̆1 ve güvenliği, dünyada yaşanan büyük facialar ve çok sayıda kişinin yaşamını kaybetmesi ile gerek ulusal gerekse uluslararası boyutta önemini gün geçtikçe arttırmaktadır. Günlük hayatta her saniye yüzlerce insan iş kazalarına maruz kalarak yaşamını yitirmekte veya çalışamaz hale gelebilmektedir. Günümüzde çalışma ve çalışma ortamlarından kaynaklı sorunlar, uyuşturucu ve savaşlardan çok daha fazla insanın ölümüne neden olmuştur. Savaşlar sebebiyle her yıl yaklaşık 650 binin üzerinde insan hayatını kaybederken, iş kazaları ve meslek hastalıklarından dolayı her yıl ortalama 2.7 milyonun üzerinde insan yaşamını yitirmektedir. Ayrıca yaklaşık olarak 2 milyon çalışan meslek hastalıklarına yakalanmakta, günlük 1000 çalışanın ise iş kazasına maruz kalarak yaşamını yitirdiği bilinmektedir (Öçal ve Çiçek, 2017: 619).

\section{B- İş Güvenliği Uzmanlığı}

Türkiye’de ilk kez 2003 yılında yapılan 4857 sayılı İş Kanunu'nun 82. md.'sinde “Sanayiden sayılan, devamlı olarak en az 50 işçi çalıştıran ve altı aydan fazla sürekli işlerin yapıldığ 1 iş yerlerinde iş güvenliği ile ilgili görevi mühendis veya teknik elemanlarının görevlendirilmesi yükümlülüğü’ getirilmiştir. Kanun'da iş güvenliği uzmanı kavramı ile ilgili doğrudan bir tanım yapılmamış olup, ilk kez 20/01/204 tarihli Yönetmelikte değinilmişti (Demircioğlu, 2006: 113). Bu düzenleme sonrasında çağın gerekleri göz önünde bulundurularak tüm çalışma alanlarını ve tüm çalışanları da kapsayan, proaktif bir yaklaşımı benimseyen, tüm çalışanları bu sürece dâhil eden ve işverenlerin yükümlülükleri üzerine şekillenen 6331 sayılı İş Sağlığı ve Güvenliği Kanunu 30/06/2012 tarihinde yürürlüğe girmiştir (Kılkış, 2014: 252). Yapılan yeni düzenleme bazı yönetmelikler ile desteklenmiştir.

İş güvenliği uzmanlığı konusunda, İş Sağlığı ve Güvenliği Kanunu ile aynı tarihte çıkarılan İş Güvenliği Uzmanlarının Görev, Yetki, Sorumluluk ve Eğitimleri Hakkında Yönetmeliğin 7. ve 8. md.'lerinde kimlerin uzman olabilecekleri belirtilmiştir. Buna göre çalışma alanları tehlike boyutuna göre, çok tehlikeli, tehlikeli ve az tehlikeli olmak üzere 3 grupta sınıflandırılmıştır. A sınıfı iş güvenliği uzmanları bütün tehlikeli çalışma ortamlarına, B sınıfı iş güvenliği uzmanları tehlikeli ve az tehlikeli ortamlara, $\mathrm{C}$ sınıfı iş güvenliği uzmanları ise az tehlikeli çalışma ortamlarına bakmakla yükümlüdür. Adı geçen yönetmeliğin 8.md.'sine göre; mühendislik veya mimarlık eğitimi veren fakülte mezunları, Bakanlık ve ilgili birimlerinde çalışma hayatını denetleyen müfettişler ile teknik elemanlar (teknik öğretmen, fizikçi, kimyager ve biyolog unvanına sahip olanlar ile iş sağlığı ve güvenliği programı mezunları) iş güvenliği uzmanı olma hakkına sahiptir.

İş güvenliği uzmanları, iş yerlerinin iş güvenliği açısından İş Sağlığı ve Güvenliği Kanunu ve ilgili yönetmeliklere göre uygun olup olmadığını denetler. İş yerlerinin uygun olmadığı durumlarda işverene yazılı ve sözlü bildirimde bulunarak gerekli önlemlerin alınmasını talep ederler. İşverenlere danışmanlık ve rehberlik yapmak, işletme ile ilgili mevcut risklerin değerlendirmesini yapmak, çalışma alanlarının gözetimini yapmak, çalışanları ve işverenleri tehlikelere karşı bilgilendirmek iş güvenliği uzmanlarının başlıca görevlerindendir. Ayrıca çalışanlara iş sağlığı ve güvenliği temel eğitimi vermek, işletme acil durum planını hazırlamak, yangından korunma dokümanı hazırlamak, kazaların kök analiz sebeplerini hazırlamak (kaza sonrası), patlamadan korunma dokümanı hazırlamak ve ilgi alanı ile ilgili diğer birimler ile iş birliği yapmak gibi görevleri de bulunmaktadır (Selek, 2016: 41). İş Sağlığı ve Güvenliği Yönetmeliği'nin 5.md.'sine göre işveren iş yerinde iş ile ilgili her konuda çalışanların sağlık ve güvenliğini korumakla yükümlüdür. İşverenin, iş sağllğı ve 
güvenliği kapsamında işyeri dışında iş sağlığı ve güvenliği ile ilgili hizmet alması işverenin sorumluluğunu ortadan kaldırmamaktadır.

İş kazası ve sonrasında adli yargılama süreçlerinde kazanın ortaya çıkış nedeni işverenin yapmakla yükümlü olduğu hususlarda ve diğer etkileyici unsurlarda dikkate alınmaktadır. Nitekim bu husus ile ilgili Yargıtay içtihatlarında istikrarlı bir şekilde işverenin sorumluluğu tehlike sorumluluğuna dayandırılmış, işletmeye özgü ortaya çıkan kayıplardan işverenin kusuru bulunmasa dahi tehlike esası göz önünde bulundurularak kusursuz sorumlu olacağı belirtilmiştir (Demircioğlu ve Kalyon, 2013: 49). Bu nedenle iş güvenliği uzmanları, işveren veya tepe yönetimin ihtiyaç ve sorunlarının tespitini iyi anlamalı ve onlarla etkili iletişim kurabilmelidir. Böylelikle iş güvenliği ile ilgili yapılması planlanan uygulamaların ve fikirlerinin işveren tarafından kabul görmesi daha kolay olacaktır (Ryan, 1989: 18-19). Uluslararası Çalışma Örgütü (ILO) tarafından, 2017 yılında iş güvenliği uzmanlarının görev ve sorumluluklarının yürütülmesi ile ilgili yapılan araştırmada, iş güvenliği uzmanlarının karşılaştıkları sıkıntılara değinilmiştir. Yapılan araştırmada, iş güvenliği uzmanlarının işverenlere çok fazla bağımlı olduğu ve bu durumun iş güvenliği uzmanlarının tespitlerinin kapasitesini sınırlandırdığ ortamlarının kötü olması, düşük maaşlara çalıştırılmaları, çalıştıkları iş yerleri için olumsuz rapor yazmaları durumunda sektörde bir daha çalışamayacaklarına dair işverenler tarafından baskı yapıldığı tespit edilmiştir (ILO, 2017: 47).

\section{C- Bilirkişilik Mevzuatı ve İş Güvenliği Uzmanlığı Bilirkişiliği}

Bilirkişi kavramı mevzuatta, çözümü uzmanlık, özel veya teknik bilgi gerektiren durumlarda, oy ve görüşünü sözlü ya da yazılı olarak sunan gerçek veya özel hukuk kişisi olarak tanımlanmıştır (Bilirkişilik Kanunu md.2, Bilirkişilik Yönetmeliği md.4). Bilirkişilik kavramı mevzuat dışında bazı kaynaklarda ise şu şekilde tanımlanmıştır; belirli konulardan iyi anlayan, yaşanan anlaşmazlıkları çözümlemek için uzmanlığına başvurulan kişi (Türkçe Sözlük, C. 1, Türk Dil Kurumu, Ankara 1988), doktrinde ise ispata dayalı bir çözümde uzmanlık gerektiren bir konu ile ilgili uzmanlık bilgisiyle mahkemeye, hâkim ve savcıya yardımcı olan, kural olarak mahkeme tarafından atanan ve görülmekte olan davanın seyrinde etkili olan kişiler (Mecek, 2011: 4-5), bir diğer tanıma göre ise, hakim tarafindan anlaşılamayan ve açıklık getirilmesi gereken uzmanlık ve teknik bilgi gerektiren veya özel bir bilgi konusunda uzmanlığına başvurulan üçüncü kişilerdir (Yücel, 2008: 48). Bilirkişi, yargılama süreçlerinde teknik nedenlerden dolayı hâkimin sonuca ulaşamadığı durumlarda, hazırlayacağı bilirkişi raporu ile hukuki sürecin işleyişine katkı sağlamaktadır. Adli yargılamalarda bilirkişi atamasını, mahkeme veya hâkim yapmaktadır. Soruşturma sürecinde ise bu yetkiyi Cumhuriyet Savcısı da kullanabilmektedir.

Hâkimin özel veya teknik bilgi gerektirdiği durumlarda, bilirkişinin bilgisine ve görüşüne başvurması kaçınılmazdır. Bu durum adli hakikatin ortaya çıkması açısından ciddi önem arz etmektedir. Ancak adli yargılama süreçlerinde bilirkişiye başvurulması ve bilirkişi raporlarının hazırlanmasının yanı sıra bilirkişilerce hazırlanan bilirkişi raporlarının hâkimi bağlaması gerektiği hususunda Yargıtay'ın tutumu bu kurumdan beklenilen amaca gölge düşürebilmektedir. Bu durum, bilirkişi kurumuna yönelik eleştirilere maruz kalmasına neden olabilmektedir. $\mathrm{Bu}$ nedenle bilirkişi kurumu tekrar ele alınarak köklü değişiklikleri yapılmasına ihtiyaç duyulmuştur (Ulukap1, 2001: 206-207). Hukuk sistemi içerisinde yargılama süreçlerine etki eden ve yargı mercilerinin vereceği kararlara özel ve teknik bilgi anlamında bir açıklama getiren bilirkişilik müessesesi, yapılan yeni düzenlemelerle bir takım gelişmelerin yaşandığı bir uygulama alanı haline dönüşmüştür. 
Adalet Bakanlığı tarafından hazırlanarak TBMM’ye sunulan Kanun Tasarı'sında ayrı bir bilirkişilik kanunun hazırlanması "Genel Gerekçe" kısmında "Günümüz hukuki ihtilaflarının giderek çeşitlenen karmaşık ve çözüm için teknik bilgi gerektiren yapısı, bilirkişilik kurumunun yargı faaliyetleri içindeki rolü ve önemini daha arttırmaktadır." şeklinde ifade ile geçmişte yaşanmış bazı sorunların tekrar yaşanmasının önüne geçilmesi amaçlanmıştır (Atalı, 2016: 3272). Bu kapsamda 24/11/2016 tarihinde 6754 sayılı Bilirkişilik Kanun’u çıkarılmış ve birtakım düzenlemeler yapılmıştır. Yapılan değişiklilerden birkaçı şu şekilde sıralanabilir; yeni Bilirkişilik Kanun'u ile bilirkişilik temel eğitimini tamamlamış olmak, bilirkişilik yapacağı uzmanlık alanında fiilen en az beş yıl (2016 yılı öncesinde mevzuatta mevcut olan süre üç yıl olarak belirlenmiştir) çalışmış olmak, 2016 yılı öncesinde bilirkişi olabilmek için başvuru tarihi itibari ile yirmi beş yaştan küçük olmama şartı yapılan yeni düzenleme ile kaldırılmıştır. Yeni bilirkişi düzenlemesine göre mahkemece yapılan görevlendirmelerin, Bilirkişilik Bölge Kurulları'na kayıtlı ve sicil numarası bulunan bilirkişiler arasından yapılması gerekmektedir. Fakat talep edilen uzmanlık bilgisine sahip bilirkişilerin, Bilirkişilik Bölge Kurulları'nda bulunmaması durumunda en yakın Bilirkişi Bölge Kurul listesine başvuru yapılacağı belirtilmiştir. Başvurulan Bilirkişilik Bölge Kurulu'nda da uzman ve teknik bilgiye sahip kişinin olmaması durumunda, mahkeme o alanda uzman ve teknik bilgiye sahip birini bilirkişi olarak atayabilmektedir. Aynı zamanda mahkeme bu durumda görevlendirdiği bilirkişiyi Bilirkişilik Bölge Kurulu'na bildirmesi gerekmektedir (Bilirkişilik Daire Başkanlığı, 2018).

6754 sayılı Bilirkişilik Kanunu'nun 10. md.'sine göre; bilirkişilik eğitimini tamamlamış olanlar, başka bir bölge kurulunun listesinde olmayanlar, bilirkişilik yapacağı alanda en az beş yıl fiilen çalışmış olanlar, meslek mensubu olarak görev yapabilmek için gerekli mevzuatta belirtilen şartları taşıyor olmak ve mesleğini yapabilmek için gerekli yeterlilik belgesine sahip olanlar, bilirkişilik temek ve alt uzmanlık alanlarına göre belirlenen yeterlilik koşullarını sağlamış olanlar bilirkişilik başvurusunda bulunabilmektedir. 26/09/2004 tarihli ve 5237 sayılı Türk Ceza Kanunu'nun 53. md.'sinde belirtilen süreler geçmiş olsa bile; kasten işlenen bir suçtan dolayı bir yıldan fazla süreyle hapis cezasına veyahut affa uğramış olsa dahi Devletin güvenliğine karşı suçlar, Anayasal düzene ve bu düzenin işleyiş̧ine karşı suçlar, zimmet, kaçakçılık, yalan tanıklık ve yalan yere yemin gibi suçlardan mahkum olanlar, daha önce kendi isteği dışında bilirkişilikten çıkarılmış olanlar, disiplin yönünden meslekten veya memuriyetten çıkarılmış olanlar veya mesleki faaliyetlerden geçici veya sürekli yasaklanmış olanlar ile daha önce başvuru yapmış olan ancak mesleki olarak yeterli nitelikte bulunmadığı gerekçesiyle reddedilenler bir yılı geçmedikçe yeniden bilirkişiliğe başvuru yapamazlar. Ayrıca hukuk öğrenimi görmüş kişiler, hukuk alanı dışında ayrı bir uzmanlığa sahip olduğunu ve birinci fıkradaki koşulları taşıdığını belgelendirmedikleri durumda, bilirkişilik siciline ve listesine kaydedilmezler.

Bilirkişilik Daire Başkanlığının 29/11/2017 tarihli Bilirkişiliğe Kabule ve Bilirkişilik Başvuru Usul ve Esaslarına İlişkin Duyurusu ile bilirkişilik bölge kurulları tarafından Bilirkişilik Kanunun 8.md.' sinin birinci fikrasının (b) ve (c) bentlerinde yer alan bilirkişilik sicili ve bölge bilirkişilik listelerinin oluşturulmasına esas olmak üzere Bilirkişilik Daire Başkanlığı tarafından belirlenen temel ve alt uzmanlık alanında belirtilen hususlar doğrultusunda bilirkişi olarak başvuru yapılabilmekteydi. Bu kapsamda Bilirkişilik Daire Başkanlığı tarafından temel ve alt uzmanlık alanlarına ilişkin hususlar tanımlanmıştır.

Ancak iş kaza yargılamalarında iş güvenliği uzmanlığı bilirkişileri ile ilgili bilirkişilik temel ve alt uzmanlık alanları ile aranan nitelikler hususuna değinilmemiştir. Bilirkişilik temel ve alt uzmanlık alanları halk sağlığında yer alırken, uygulama alanı olarak ise iş sağlığı şeklinde 
açıklanmıştır. Bilirkişilik Daire Başkanlığının 2018 yılı 2. dönem bilirkişilik başvurularına ilişkin duyurusunda ise, 29/11/2017 tarihli bilirkişiliğe kabule ve bilirkişiliğe başvuru ve esaslarına ilişkin temel ve alt uzmanlık alanlarında birtakım düzenlemeler yapılmıştır. Ek2'deki bilirkişilik temel ve alt uzmanlık alanlarına göre aranan nitelikler kısmında yer alan uzmanlık alanına, iş sağlığı ve güvenliği başlığı eklenmiştir. Temel uzmanlık ve alt uzmanlık alanlarına ilişkin listede 831 sıra numarasında 63 ana kod ile "iş sağlığı ve güvenliğii" uzmanlık alanı eklenmiştir. Yapılan düzenlemeler, arasında belki de en önemlisi, özel ve teknik bilgi sahibi kişilere dair nitelik kodlarının belirlenmesidir. Bu kapsamda iş kazalarında görevlendirilecek iş güvenliği uzmanlığı bilirkişilerinde aranan niteliklerde aşağıdaki hususlara değinilmiştir. Bilirkişilik Kanunu'nun 10.md.'si ve Bilirkişilik Yönetmeliği'nde yer alan 38.md.'sindeki koşulları taşıyan, İş Sağlığı ve Güvenliği Genel Müdürlüğü’nce verilen $A, B$ veya $C$ sınıfı iş güvenliği uzmanlığı belgesine sahip olan, Aile ve Çalışma Sosyal Hizmetler Bakanlığı veya bağlı kuruluşlarda iş sağlı̆̆ ve güvenliği alanında uzman veya müfettiş kadrolarında çalışan veya çalışmış olan kişiler bilirkişilik başvurularında bulunabilirler. Ayrıca Bilirkişilik Kanunu'nun 11.md.'sinin üçüncü fikrasında “Bölge kurulları karar verirken sicile kayıt bakımından öncelikle başvuranın 10. md.'sindeki şartları taşıyıp taşımadığını değerlendirir ve şartları taşıyanlar arasından başvuranın mesleki tecrübesini, katıldığı meslek içi eğitimleri veya uzmanlık gösteren belgeleri dikkate alarak en liyakatli olanları seçer." hükmü yer almaktadır. Başvuranlar arasından liyakatli olanların belirlenmesinde, uzmanlık alanı kapsamında doktora veya yüksek lisans yapmış olanlar ile uzmanlık alanlarında mesleki gelişim, meslek içi eğitim, akademik ve mesleki çalışmalar ve mesleki başarıları bulunanlar dikkate alınarak değerlendirme yapılır.

\section{D- Araştırmanın Amacı ve Önemi}

Türkiye'de yaşanan ve bir türlü önlenemeyen iş kazaları ve bu kazaların soruşturulma süreçlerinde yaşanan sorunlar ülke gündemini gereğinden fazla meşgul etmektedir. Mahkemeler bu davaların çözüme kavuşturulması ve kusur oranlarının belirlenmesi aşamasında yetersiz kaldıkları durumlarda, alanında uzman, çözümleyici ve teknik bilgiye sahip bilirkişileri görevlendirebilmektedir. Bilirkişiler alanında teknik yeterliliğe sahip ve mevzuatın zorunlu tuttuğu yetkinliğe sahip kişilerden olmak zorundadır. Gün geçtikçe önem kazanan bilirkişilik müessesesi 2016, 2017 ve 2018 yıllarında yapılan düzenlemeler ile kurumsal bir yapıya dönüştürülmeye çalışılmıştır.

Kurumsal yapının kazandırılmasında, kuşkusuz yargılama süreçlerinde önemli role sahip olan nitelikli kişilerin bilirkişi olarak sisteme dâhil edilmesi gerekmektedir (Kök, 2017: 447). İş güvenliği uzmanı olan bilirkişiler, Kanun ve yönetmelikler çerçevesinde, teknik bilgileri dahilinde belirledikleri tespitlerini adli makamlara rapor halinde yazılı veya gerekli görüldügü takdirde sözel olarak sunarlar. İş kazalarındaki kusur tespitini ortaya koyan bu raporlar yargılama sürecine katkı sağlamaktadır. Aynı zamanda bilimsel çalışmalara ışık tutmakta ve muhtemel benzer iş kazalarının önlenmesinde yol gösterici olabilmektedir.

$\mathrm{Bu}$ bağlamda görevlendirilen iş güvenliği uzmanlığı bilirkişilerinin alanlarındaki yetkinlikleri, kaza kusur oranlarının araştırılması ve bu aşamada maruz kaldıkları baskı, şiddet ve yönlendirmeler, mesleki branş dağılımının önemi, yeni bilirkişilik düzenlemesinin iş güvenliği uzmanlığı bilirkişiliğine etkisi, bilirkişilerin mahkeme boyutu ve görevlendirilme aşamasında yaşanan benzeri sorunlar tespit edilerek bu sorunlara çözüm önerileri bulunmaya çalışılmıştır. 


\section{E- Araştırma Yöntemi}

Adalet Bakanlığının 2018 yılı verilerine göre adli sisteme kayıtlı 2082 iş güvenliği uzmanlığı bilirkişisi bulunmaktadır (Bilirkişilik Daire Başkanlığı, 2018). Fakat bilirkişilik siciline kaydı bulunmayan ancak iş güvenliği uzmanlığı bilirkişiliği yapmakta olan bilirkişilerin sayısı bilinmemektedir. Bu çalışma iş güvenliği uzmanlığı bilirkişilerinin adli bilirkişi siciline kayıtlı bilirkişiler ve bilirkişi siciline kayıtlı olmayan ancak iş kazalarında bilirkişi olarak görev yapan iş güvenliği uzmanlarını kapsamaktadır.

Araştırmada kullanılan sorular; Bilgin ve Kılıç tarafından 2018 yılında Sosyal Hizmet Uzmanlarının Bilirkişilik Uygulamaları Hakkında yapılmış olan araştırmanın (Bilgin ve Kılıç, 2018) araştırma sorularının İş güvenliği uzmanlarının bilirkişilik uygulamalarına uyarlanarak gerçekleştirilmiştir. Uyarlanan araştırma sorularına; iş güvenliği uzmanlığı bilirkişilerinin meslek dağılımları, iş kazalarında oluşturulan bilirkişi komisyonunda karşılaşılan sorunlar, iş kazalarının ortaya çıkmasında etki eden faktörler, iş güvenliği uzmanlığı bilirkişilerinin sahip olduğu belgeler konularında sorular eklenmiştir.

$\mathrm{Bu}$ kapsamda uyarlanan araştırma soruları 29 sorudan oluşmakta olup tarama modelli tanımlayıcı bir çalışmadır. Araştırma soruları iş kazalarında iş güvenliği uzmanlığı bilirkişisi olarak görev alan (bilirkişilik siciline kayıtlı olup olmadığı gözetilmeksizin) 65 katılımcıdan oluşmaktadır. Araştırma soruları demografik bilgileri de kapsayan çoktan seçmeli ve açık uçlu sorulardan oluşmaktadır.

Araştırmaya katılan 65 katılımcının 59'unun bilirkişi siciline kayıtlı olduğu, 6'sının bilirkişi siciline kayıtlı olmadığı belirlenmiştir. Değerlendirmeler 65 kişi üzerinden yapılmıştır. Araştırma örneklemi, Türkiye evreninde iş güvenliği alanında adli bilirkişilik yapan kişilerden oluşmaktadır. Hazırlanan anket formu ön test amacıyla 5 katılımcı üzerinde test edilmiş ve sonrasında 05/01/2019 ile 15/01/2019 tarihleri aralığında iş güvenliği uzmanlığ bilirkişilerine internet üzerinden çevrimiçi olarak uygulanmıştır. Araştırma sonucunda 105 bilirkişi ankete katılım sağlamış ancak 40 ankete eksik ve hatalı cevaplar verilmesinden dolayı 65 katılımcıya ait anketler araştırmaya dahil edilmemiştir. Yapılan bu bilimsel araştırma verileri SPSS 21 programı ile analiz edilerek, betimleyici istatistiklere ulaşılmıştır.

\section{F- Analiz ve Bulgular}

Tablo 1. İ̧ Güvenliği Uzmanlığı Bilirkişilerinin Cinsiyet, Yaş ve Medeni Durumlarına Ait Bilgiler

\begin{tabular}{lcc}
\hline Değişken & Sayı(n) & Yüzde (\%) \\
\hline Cinsiyet & 17 & 26,16 \\
\hline Kadın & 48 & 73,84 \\
\hline Erkek & $\mathbf{6 5}$ & $\mathbf{1 0 0}$ \\
\hline Toplam & & 40 \\
\hline Yaş dağılımı & 26 & 32,31 \\
\hline $30-39$ yaş arası & 21 & 18,46 \\
\hline $40-49$ yaş arası & 12 & 9,23 \\
\hline $50-59$ yaş arası & 6 & $\mathbf{1 0 0}$ \\
\hline 60 ve üzeri & $\mathbf{6 5}$ & \\
\hline Toplam & & 84,61 \\
\hline Medeni durum & 55 & 15,39 \\
\hline Evli & 10 & $\mathbf{1 0 0}$ \\
\hline Bekar & $\mathbf{6 5}$ & \\
\hline Toplam & &
\end{tabular}


Tablo 1 incelendiğinde araştırmaya katılan iş güvenliği uzmanlığ 1 bilirkişilerinin \%73,84'ü erkek, \%26,16'sı kadınlardan oluşmaktadır. Yaş dağılımları incelendiğinde katılımcıların \%40'ının 30-39 yaş aralığında, \%32,31'inin 40-49 yaş aralığında, \%18,46'sının 50-59 yaş aralığında, \%9,23'ünün ise 60 yaş ve üzeri aralığında olduğu görülmektedir. Ayrıca katılımcıların \%84,61'inin evli, \%15,39'unun bekâr olduğu tespit edilen diğer bir sonuçtur.

Tablo 2. Işs Güvenliği Uzmanlı̆̆ Bilirkişilerinin Ö̆grenim Düzeyleri, Meslekleri ve Meslekte Geçirdikleri Sürelere Ait Bilgiler

\begin{tabular}{lcc}
\hline Değişken & Sayı(n) & Yüzde (\%) \\
\hline Öğrenim düzeyi & 31 & 47,69 \\
\hline Lisans & 27 & 41,54 \\
\hline Yüksek Lisans & 7 & 10,77 \\
\hline Doktora & $\mathbf{6 5}$ & $\mathbf{1 0 0}$ \\
\hline Toplam & 7 & 10,77 \\
\hline Meslekte geçirilen çalışma süresi & 11 & 16,91 \\
\hline $1-4$ yıl & 11 & 16,91 \\
\hline $5-9$ y1l & 8 & 12,31 \\
\hline $10-14$ y1l & 28 & 43,10 \\
\hline $15-19$ yıl & $\mathbf{6 5}$ & $\mathbf{1 0 0}$ \\
\hline 20 y1l ve üzeri & & 20 \\
\hline Toplam & 13 & 9,23 \\
\hline Meslek dağılımı & 6 & 10,70 \\
\hline Maden Mühendisliği & 7 & 7,7 \\
\hline Kimya Mühendisliği & 5 & 6,15 \\
\hline Makine Mühendislĭgi & 4 & 9,22 \\
\hline İnşaat Mühendisliği & 6 & 37 \\
\hline Ziraat Mühendisliği & 24 & $\mathbf{1 0 0}$ \\
\hline Çevre Mühendisliği & $\mathbf{6 5}$ & \\
\hline Diğer meslek dalları & & \\
\hline Toplam & & \\
\hline \hline
\end{tabular}

Araştırmaya katılanların \%47,69'u lisans mezunu, \%41,54'ü yüksek lisans mezunu, $\% 10,77$ 'sinin ise doktora mezunu olduğu belirlenmiştir. Katılımcıların mezun oldukları meslekte geçirdikleri çalışma süreleri açısından bakıldığında ise, \%43,10'unun 20 yıl ve üzeri çalıştığ $, \% 16,91$ 'inin 5-9 yıl çalıştı̆̆ $1, \% 16,91$ 'inin 10-14 yıl çalıştığ $1, \% 12,31$ 'nin 15-19 yıl çalıştığı, \%10,77 'sinin ise 1-4 yıl çalıştığı tespit edilmiştir. Katılımcıların \% 37'si farklı meslek gruplarından oluşmakta olup \%20'si maden mühendisi, \%10,70'i makine mühendisi, \%9,23'ü kimya mühendisi, \%9,22'si çevre mühendisi, \%7,7'si inşaat mühendisi, \%6, 15'i ise ziraat mühendisi meslek grubundadır.

Tablo 3. İş Güvenliği Uzmanlı̆̆ Bilirkişilerinin Görev Yaptıkları Kurumlara Ait Bilgiler

\begin{tabular}{lcc}
\hline Değișken & & \\
\hline Görev yapılan kurum & Sayı(n) & Yüzde(\%) \\
\hline Kamu & 17 & 26,16 \\
\hline Özel & 34 & 52,30 \\
\hline Üniversite & 14 & 21,54 \\
\hline Toplam & $\mathbf{6 5}$ & $\mathbf{1 0 0}$ \\
\hline
\end{tabular}

Tablo 3'e göre iş güvenliği uzmanlığı bilirkişilerinin \%52,30'unun özel sektörde çalıştığı, \%26,16'sının kamuda çalıştığ1, \%21,54'nün ise üniversitelerde istihdam edildikleri belirlenmiştir. Dolayısı ile araştırmaya katılan iş güvenliği uzmanlığı bilirkişilerinin yarısından fazlası özel sektörde istihdam edilmektedir. 
Tablo 4. İ̧̧ Güvenliği Uzmanlı̆̆ı Bilirkişilerinin Bilirkişilik Siciline Kayıtlı Olma Durumu ve Bilirkişilik Yapma Sürelerine Ait Bilgiler

\begin{tabular}{lcc}
\hline Değişken & & Sayı(n) \\
\hline Bilirkişilik siciline kayıt durumu & 59 & Yüzde (\%) \\
\hline Evet kayıtlııım & 6 & 90,77 \\
\hline Hayır, kayıtlı değilim & $\mathbf{6 5}$ & 9,23 \\
\hline Toplam & & $\mathbf{1 0 0}$ \\
\hline Bilirkişilik yapma süresi & 36 & 55,38 \\
\hline $1-3$ yıl & 13 & 20 \\
\hline 4-6 yıl & 3 & 4,62 \\
\hline 7-9 yıl & 13 & 20 \\
\hline 10 yıl ve üzeri & $\mathbf{6 5}$ & $\mathbf{1 0 0}$ \\
\hline Toplam & &
\end{tabular}

Araştırmada katılımcılara iş güvenliği uzmanlığ olma durumu ve bilirkişilik alanında çalışma süreleri sorulmuştur. Elde edilen verilere göre katılımcıların \% 90,77'sinin bilirkişilik siciline kayıtlı olduğu, \% 9,23'nün ise bilirkişilik siciline kayıtlı olmadıkları halde bilirkişilik yaptıkları tespit edilmiştir. Ayrıca katılımcıların \%55,38'inin 1-3 yıl, \% 20’nin 4-6 yıl, \% 20'sinin 10 yıl ve üzeri, \%4,62'sinin ise 7-9 yıl bilirkişilik yaptıkları tespit edilmiştir.

Tablo 5. İş Güvenliği Uzmanlı̆̆ı Bilirkişilerinin 2018 Yılı Bilirkişilik Yaptıkları Dosya Sayılarına Ait Bilgiler

\begin{tabular}{lcc}
\hline Değişken & & \\
\hline Dosya sayısı & Sayı(n) & Yüzde (\%) \\
\hline $1-4$ dosya & 24 & 36,92 \\
\hline 5-9 dosya & 8 & 12,31 \\
\hline 10-14 dosya & 2 & 3,07 \\
\hline 20 dosya ve üzeri & 31 & 47,70 \\
\hline Toplam & $\mathbf{6 5}$ & $\mathbf{1 0 0}$ \\
\hline
\end{tabular}

Tablo 5 iş güvenliği uzmanlığı bilirkişilerinin 2018 yılında bilirkişilik yaptıkları dosya sayılarını göstermektedir. Katılımcıların \% 47,70'inin 20 ve üzeri dosya, \%36,92'sinin 1-4 dosya, \%12,31'inin 5-9 dosya, \%3,07'sinin 10-14 dosyada bilirkişilik yaptıkları belirlenmiştir.

Tablo 6. İ̧̧ Güvenliği Uzmanlığ Bilirkişilerinin Görevlendirilme Şekillerine Ait Bilgiler

\begin{tabular}{lcc}
\hline Değişken & & \\
\hline Görevlendirilme şekli & Sayı(n) & Yüzde (\%) \\
\hline Bilirkişi Portalı UYAP üzerinden & 4 & 6,15 \\
\hline Görev yaptı̆̆ım kuruma üst yazı yazılarak & 1 & 1,54 \\
\hline Mahkeme kalemi tarafından telefon ile aranarak & 60 & 92,31 \\
\hline Toplam & $\mathbf{6 5}$ & $\mathbf{1 0 0}$ \\
\hline
\end{tabular}

Araştırmaya katılan iş güvenliği uzmanlığı bilirkişilerinin, bilirkişilik dosyalarında görevlendirme şekilleri ile ilgili olarak katılımcıların \%92,31'inin mahkeme kalemi tarafından telefon ile aranarak bilgi verilmek suretiyle, \%6,15'inin Bilirkişi Portalı UYAP üzerinden, \%1,54'ünün mahkeme tarafindan görev yaptığı kuruma görevlendirme yazılarak görevlendirildikleri belirlenmiş̧ir. Yapılan yeni bilirkişilik düzenlemesi ile bilirkişilerin görevlendirilmesi, raporların hazırlanması, görevin kabul edilmesi veya reddedilmesi, ek süre talep etmesi gibi hususlar artı UYAP bilirkişilik portal aracılığııla gerçekleştirilmektedir. 
İş Güvenliği Uzmanlığı Bilirkişileri Üzerine Bir Çalışma

Tablo 7. Bilirkişi Raporlarının Mahkemeye Sunulma Yöntemine Ait Bilgiler

\begin{tabular}{lcc}
\hline Değişken & Sayı (n) & Yüzde(\%) \\
\hline Sunulma Yöntemi & & \\
\hline Mahkeme kalemine elden teslim & 59 & 90,76 \\
\hline Mahkeme kaleminin posta ile gönderim & 2 & 3,08 \\
\hline Bilirkişi Portalı UYAP üzerinden gönderim & 4 & 6,16 \\
\hline Toplam & $\mathbf{6 5}$ & $\mathbf{1 0 0}$ \\
\hline
\end{tabular}

Araştırmada iş güvenliği uzmanlığı bilirkişilerinin 2018 yılında düzenlemiş oldukları bilirkişi raporlarını \%90,76'sının mahkeme kalemine elden teslim ettiği, \%6,16'sının mahkeme Bilirkişi Portalı UYAP üzerinden gönderdiği, \%3,08'inin ise mahkeme kalemine e-posta yoluyla ilettiği tespit edilmiştir.

Tablo 8. Bilirkişi Raporlarının Mahkemeye Sunulma Süresine Ait Bilgiler

\begin{tabular}{lcc}
\hline Değişken & Sayı(n) & Yüzde(\%) \\
\hline Süre & & \\
\hline 1-2 hafta & 24 & 36,92 \\
\hline 3-5 hafta & 32 & 49,23 \\
\hline 6-8 hafta & 6 & 9,23 \\
\hline 9 hafta ve üzeri & 3 & 4,62 \\
\hline Toplam & $\mathbf{6 5}$ & $\mathbf{1 0 0}$ \\
\hline
\end{tabular}

Araştırmada iş güvenliği uzmanlığı bilirkişilerinin hazırladıkları raporları \%49,23'ünün 3-5 hafta, \%36,92'sinin 1-2 hafta, , \%9,23’ünün 6-8 hafta, \%4,62'sinin ise 9 hafta ve üzeri sürede mahkemeye sundukları belirlenmiştir. Bilirkişi raporlarının mahkemeye sunulmasında azami süre üç aydır. Ancak Bilirkişilik Kanunu'na göre bilirkişinin talep etmesi durumunda bu süre üç ayı geçmeyecek şekilde uzatılabilmektedir.

Tablo 9. Bilirkişi Raporlarına Yönelik Mahkemelerin En Az Bir Kez Aksi Yönde Karar Verme Durumuna Ait Bilgiler

\begin{tabular}{lcc}
\hline Değişken & Sayı (n) & Yüzde(\%) \\
\hline En az bir kez aksi yönde karar verme durumu & & \\
Evet, verildi & 12 & 18,46 \\
\hline Hayır, verilmedi & 53 & 81,54 \\
\hline Toplam & $\mathbf{6 5}$ & $\mathbf{1 0 0}$ \\
\hline
\end{tabular}

Araştırmada iş güvenliği uzmanlığı bilirkişilerce hazırlanan raporlardaki mesleki değerlendirme ve tespitlerin, görevlendirme yapan mahkemelerce aksi yönde karar ile ilgili soruya, katılımcıların \%81,54'ü bir kez dahi aksi yönde karar verilmediğini, \%18,46's1 ise en az bir kez aksi yönünde karar verildiğgini belirtmiştir.

Tablo 10.Bilirkişi Raporları için Mahkemelerin Takdir Ettiği Ortalama Bilirkişi Ücretlerine Dair Bilgiler

\begin{tabular}{lcc}
\hline Değişken & Sayı (n) & Yüzde(\%) \\
\hline Ortalama bilirkişilik ücreti & & \\
\hline $100-199$ TL & 10 & 15,38 \\
\hline $200-299$ TL & 38 & 58,46 \\
\hline $300-399$ TL & 12 & 18,46 \\
\hline 400 TL ve üzeri & 5 & 7,7 \\
\hline Toplam & $\mathbf{6 5}$ & $\mathbf{1 0 0}$ \\
\hline
\end{tabular}


Katılımcılara, 2018 yılında hazırladıkları raporları için mahkemelerin ortalama ne kadar ücret takdir ettikleri ile ilgili soruya katılımcıların \%58,46's1 200-299 TL ücret aldıkları, \%18,46'sı 300-399 TL ücret aldıkları, \%15'i 100-199 TL ücret aldıkları, \%7,7'si ise 400 TL ücret aldıklarını belirtmişlerdir.

Tablo 11. Ișs Güvenliği Uzmanlı̆̆ Bilirkişilerinin Asgari Ücret Tarifesi Hakkında Bilgi Düzeylerine Ait Bilgiler

\begin{tabular}{lcc}
\hline Değișken & Sayı(n) & Yüzde(\%) \\
\hline Evet, bilgim var & 48 & 73,85 \\
\hline Hayır, bilgim yok & 17 & 26,15 \\
\hline Toplam & $\mathbf{6 5}$ & $\mathbf{1 0 0}$ \\
\hline
\end{tabular}

Adalet Bakanlı̆̆ı tarafından 2018 yılında yayımlanan Bilirkişilik Asgari Ücret Tarifesi Tebliği hakkında düzenlemeden katılımcıların $\% 73,85$ 'i bilgisinin olduğu, $\% 26,15$ 'i ise bilgisinin olmadı̆̆

Tablo 12. İş̧ Güvenliği Uzmanlı̆̆ Bilirkişilerinin Düzenledikleri Bilirkişi Raporları İ̧̧in Mahkemenin Takdir Ettiği Ücretin Yeterliliğine Ait Bilgiler

\begin{tabular}{lcc}
\hline Değişken & Sayı(n) & Yüzde(\%) \\
\hline Bilirkişilik ücretini yeterli bulma & & \\
\hline Evet, yeterli buluyorum & 13 & 20 \\
\hline Hayır, yeterli bulmuyorum & 52 & 80 \\
\hline Toplam & $\mathbf{6 5}$ & $\mathbf{1 0 0}$ \\
\hline
\end{tabular}

Araştırmaya katılan iş güvenliği uzmanlığı bilirkiş̧ilerinin, 2018 yılında bilirkişi raporları için takdir edilen ücreti yeterli bulup bulmadıklarıyla ilgili soruya katılımcıların \%80'inin aldıkları ücreti yeterli bulmadığı, \%20'sinin ise aldıkları ücreti yeterli bulduğu belirlenmiştir.

Tablo 13. İş Güvenliği Uzmanlığı Bilirkişilerinin Bilirkişilik Uygulamalarında "Mahkeme Boyutunda" Karşılaşılan Sorunlara Ait Bilgiler

\begin{tabular}{lcc}
\hline Değişken & Sayı (n: 65) & Yüzde(\%) \\
\hline Karşılaşılan sorun & & \\
\hline Görevlendirmenin tarafıma geç ulaşması & 8 & 12,31 \\
\hline Rapor hazırlamam için tarafıma tanınan sürenin az olması & 15 & 23,1 \\
\hline Düşük bilirkişi ücreti takdir edilmesi & 41 & 63,1 \\
\hline Davalı taraflar için hedef haline getirilmem & 4 & 6,15 \\
\hline Düzenlediğim raporların yetersiz görülmesi & 4 & 6,15 \\
\hline $\begin{array}{l}\text { Uzman olmayan kişilerin bilirkişi komisyonuna dâhil } \\
\text { edilmesi }\end{array}$ & 31 & 47,70 \\
\hline Bilirkişi olarak görevimin tam olarak belirtilmemesi & 8 & 12,31 \\
\hline Hayır, herhangi bir sorunla karşılaşmadım & 14 & 21,54 \\
\hline
\end{tabular}

Araştırmada iş güvenliği uzmanlığı bilirkişilerinin, bilirkişi olarak görev yaptıkları dosyalarda "mahkeme boyutunda" karşılaşılan sorunlarla ilgili çoktan seçmeli soruya katılımcıların \% 63,1'inin görevlendirilen dosya için düşük bilirkişi ücreti takdir edildiği, \%47,70'inin alan ile ilgili uzman olmayan kişilerin bilirkişi heyetlerine dâhil edildiği, $\% 23,1$ 'inin görevlendirme sonucu rapor hazırlanması için tanınan sürenin az olduğu, \%21,54'ünün herhangi bir sorun ile karşılaşmadığ1, \%12,31'inin görevlendirmenin taraflarına geç ulaştırıldığı, \%12,31'inin görevlendirildiği dosyalarda bilirkişi olarak görevlerinin tam olarak belirtilmediği, \% 6,15'inin görevlendirildiği dosyada davalı taraflar için hedef haline getirildiği, \%6,15'inin görevlendirildiği dosyada düzenlenen raporların yetersiz görüldüğü şeklinde sonuçlara ulaşılmıştır. 
İş Güvenliği Uzmanlığı Bilirkişileri Üzerine Bir Çalışma

Tablo 14. Işs Güvenliği Uzmanlığı Bilirkişilerinin Bilirkişilik Uygulamalarında "Taraflar Boyutunda”, Karşılaşılan Sorunlara Ait Bilgiler

\begin{tabular}{lcc}
\hline Değişken & Sayı (n: 65) & Yüzde (\%) \\
\hline Karşılaşılan sorun & & \\
\hline Baskı görme/yönlendirilme & 7 & 10,77 \\
\hline $\begin{array}{l}\text { Konuyla ilgili yeterli bilgi verilmemesi/bilgi vermekten } \\
\text { kaçınılması }\end{array}$ & 11 & 16,92 \\
\hline Adresi bulma ve iletişim kurmada sorun yaşanması & 2 & 3,07 \\
\hline Tarafların konu ile ilgili yalan söylemesi/manipüle etmesi & 12 & 18,46 \\
\hline Taraf avukatının bask1 kurmaya ve yönlendirmeye çalışması & 1 & 1,54 \\
\hline Hayır, herhangi bir sorunla karşışaşadım & 41 & 63,10 \\
\hline \hline
\end{tabular}

İş güvenliği uzmanlığı bilirkişilerinin, bilirkişi olarak görev yaptıkları dosyalarda "taraflar boyutunda" karşılaşılan sorunlarla ilgili çoktan seçmeli soruya katılımcıların \%63.10'unun herhangi bir sorunla karşılaşmadığı, \%18,46'sının tarafların konu ile ilgili yalan söylediği/manipüle ettiği, \%16,92'sinin tarafların konuyla ilgili yeterli bilgi vermediği/bilgi vermekten kaçındığı, \%10,77'sinin taraflardan baskı gördüğü/yönlendirildiği, \%3,07'sinin adres bulma ve iletişim kurmada sorun yaşandığ1, \%1,54'ünün davalı avukatın bilirkişiler üzerinde baskı kurmaya ve yönlendirmeye yönelik girişimlerinin olduğu sonuçlarına ulaşılmıştır.

Tablo 15. İ̧̧ Güvenliği Uzmanlığı Bilirkişilerinin Bilirkişilik Uygulamalarında "Bilirkişilik Komisyonu Boyutunda” Karşılaşılan Sorunlara Ait Bilgiler

\begin{tabular}{lcc}
\hline Değişken & Sayı (n: 65) & Yüzde (\%) \\
\hline Karşılaşılan sorun & 35 & 53,85 \\
\hline $\begin{array}{l}\text { Bilirkişilik komisyonunda bilirkişilik görevine esas } \\
\text { oluşturan dosya konusunda alanında uzmanlık } \\
\text { bilgisine sahip olmayan kişilerin görevlendirilmesi }\end{array}$ & 24 & 36,95 \\
\hline $\begin{array}{l}\text { Bilirkişilik komisyonunda görev alan bilirkişiler } \\
\text { arasında iletişim ve koordinasyonda gülük } \\
\text { yaşanması }\end{array}$ & 14 & 21,53 \\
\hline $\begin{array}{l}\text { Bilirkişilik komisyonunda görev alan bilirkişiler } \\
\text { tarafindan düzenlenen bilirkişi raporunda görüş̧ } \\
\text { birliğine varılamaması }\end{array}$ & 16 & 24,62 \\
\hline $\begin{array}{l}\text { Bilirkişilik komisyonunda görev alan bilirkişiler } \\
\text { arasında ortak çalışma gün ve saatinin } \\
\text { belirlenememesi }\end{array}$ & 16 & 24,62 \\
\hline $\begin{array}{l}\text { Bilirkişilik komisyonunda görev alan bilirkişiler } \\
\text { arasında görev dağılımında sorunlar yaşanması }\end{array}$ & 4 & 6,15 \\
\hline Herhangi bir sorun ile karşılaşmadım & & \\
\hline
\end{tabular}

İş güvenliği uzmanlığı bilirkişiler farklı mesleklerden oluşabilmekte ve iş kazasının niteliğine göre mahkemeler tarafından farklı mesleki yeterliliklere sahip (maden mühendisi, makine mühendisi, inşaat mühendisi vb. gibi) iş güvenliği uzmanlarından bilirkişi komisyonu oluşturularak iş kazası hakkında farklı meslek uzmanlarının görüş ve değerlendirmeleri talep edilebilmektedir. $\mathrm{Bu}$ komisyonlar, düzenlenen bilirkişi raporlarının mahkeme nezdinde 
multidisipliner bir çalışma ile iş kazasının daha kapsamlı bir şekilde incelenmesini sağlamaktadır. Bu sebeple birçok iş kazasında farklı mesleki yeterliliğe sahip uzmanlardan bilirkişi komisyonu oluşturularak iş kazası hakkında bilirkişi raporu hazırlanması beklenmektedir. Araştırma kapsamında iş güvenliği uzmanlığı bilirkişilerinin, bilirkişi olarak görev yaptıkları dosyalarda "bilirkişilik komisyonu boyutunda" karşılaşılan sorunlarla ilgili çoktan seçmeli soruya katılımcıların \%53,85'inin bilirkişilik görevine esas oluşturan dosya konusunda alanında uzmanlı bilgisine sahip olmayan kişilerin görevlendirildiği, \%36,95'inin bilirkişilik komisyonunda görev alan bilirkişiler arasında iletişim ve koordinasyonda güçlük yaşandığı, \%24,62'sinin bilirkişilik komisyonunda görev alan bilirkişiler arasında ortak çalışma gün ve saatinin belirlenemediği, \%24,62'sinin bilirkişilik komisyonunda görev alan bilirkişiler arasında görev dağılımında sorunlar yaşandığı, \%21,53'ünün bilirkişilik komisyonunda görev alan bilirkişiler tarafından düzenlenen bilirkişi raporunda görüş birliğine varılamadığ $1, \% 6,15$ 'inin ise herhangi bir sorun ile karşılaşmadığ belirlenmiştir.

Tablo 16.Yeni Bilirkişilik Düzenlemesinin İş Güvenliği Uzmanlığı Bilirkişilerinin Bilirkişilik Uygulamalarina Etkisine Ait Bilgiler

\begin{tabular}{lcc}
\hline Değişken & Sayı (n) & Yüzde(\%) \\
\hline Yeni bilirkişilik düzenleme nasıl değerlendiriliyor & & \\
\hline Evet, etkisi oldu & 13 & 20 \\
\hline Kısmen etkisi oldu & 29 & 44,61 \\
\hline Hayır, etkisi olmadı & 23 & 35,39 \\
\hline Toplam & $\mathbf{6 5}$ & $\mathbf{1 0 0}$ \\
\hline
\end{tabular}

Araştırmada 2016 yılında kabul edilen Bilirkişilik Kanunu ve 2018 yılı ocak ayı itibari ile güncellenen (temel ve alt uzmanlık alanları) yeni bilirkişilik düzenlemesinin iş kazalarında görev alan iş güvenliği uzmanlığı bilirkişi uygulamasına etkisinin olup olmadığı araştırılmıştır. Yapılan araştırmada yeni bilirkişi düzenlemesinin katılımcıların \%44,61'i kısmen olumlu etkilediği, \%35,39'una herhangi bir etkisinin olmadı̆̆ 1 , \%20'sini ise olumlu yönde etkilediği belirlenmiştir.

Tablo 17. İ̧s Güvenliği Uzmanlığı Bilirkişilerinin Bilirkişilik Görevlendirmelerinde Mahkemeler Tarafindan Bilirkişilik Siciline Kayıtlı Olma Durumuna Dikkat Edilmesine Ait Bilgiler

\begin{tabular}{lcc}
\hline Değişken & Sayı (n) & Yüzde(\%) \\
\hline Düzenlemenin etkisi & & \\
\hline Evet, ediliyor & 44 & 68,90 \\
Hayır, edilmiyor & 21 & 31,10 \\
\hline Toplam & $\mathbf{6 5}$ & $\mathbf{1 0 0}$ \\
\hline
\end{tabular}

2018 yılı ocak ayı itibari ile mahkemeler tarafından görevlendirilecek bilirkişilerin bilirkişi listelerine kayıtlı kişiler arasından seçilmesi gerektiği belirtilmiştir. Ancak dava konusu ile ilgili alanında uzman ve yetkin bir bilirkişinin bilirkişilik siciline kayıtlı bulunmaması durumunda bazı özel hükümler düzenlenmiştir. $\mathrm{Bu}$ gibi zaruri durumların dışında bilirkişilerin sicile kayıtlı bilirkişiler arasından seçilmesi gerekmektedir. Araştırmaya katılan iş güvenliği uzmanlığı bilirkişilerinin \%68,90’1 bilirkişi görevlendirmelerinde bilirkişilik siciline kayıtlı olma durumuna dikkat edildiğini belirtirken, \%31,10’u dikkat edilmediğini belirtmiştir. 
İş Güvenliği Uzmanlığı Bilirkişileri Üzerine Bir Çalışma

Tablo 18. Işs Güvenliği Uzmanlığı Bilirkişilerine Göre Yeni Bilirkişilik Düzenlemesinin Bilirkişilik Müessesesinin Gelişimine Etkisine Nasıl Bir Etkisi Olacă̆ına Ait Bilgiler

\begin{tabular}{|c|c|c|}
\hline Değișken & Sayı (n: 65) & Yüzde (\%) \\
\hline \multicolumn{3}{|l|}{ Gelişme yönü } \\
\hline $\begin{array}{l}\text { Bilirkişilik uygulamalarını standartlaştırarak } \\
\text { bilirkişiliği daha sistematik hale getirecek }\end{array}$ & 36 & 55,38 \\
\hline Bilirkişilik kurumsallaşan bir hizmet haline gelecek & 27 & 41,54 \\
\hline $\begin{array}{l}\text { Bilirkişilik müessesesine ve bilirkişiye güven } \\
\text { artacak }\end{array}$ & 25 & 38,46 \\
\hline $\begin{array}{l}\text { Yeni bilirkişilik düzenlemesi herhangi bir gelişim } \\
\text { sağlamayacak ve mevcut uygulamalar devam edecek }\end{array}$ & 22 & 33,85 \\
\hline $\begin{array}{l}\text { Yeni bilirkişilik düzenlemesi ile bilirkişilik } \\
\text { uygulamaları daha kötü bir hale gelecek }\end{array}$ & 3 & 4,15 \\
\hline
\end{tabular}

Yeni bilirkişilik düzenlemesi ile bilirkişilik müessesesinin nasıl bir gelişme göstereceği ile ilgili çoktan seçmeli soruya katılımcıların \%55,38'i bilirkişilik uygulamalarını standartlaştırarak daha sistematik hale geleceğini, \%41,54'ü bilirkişiliğin kurumsallaşan bir hizmet haline geleceğini, \%33,85'i yeni bilirkişilik düzenlemesinin herhangi bir gelişim sağlamayarak mevcut uygulamaların devam edeceğini, \%38,46'sı bilirkişilik müessesesine ve bilirkişiye güvenin artacağını, \%4,15'i ise yeni bilirkişilik düzenlemesinin bilirkişilik uygulamalarını daha kötü hale getireceğini belirtmiştir.

Tablo 19. İş Güvenliği Uzmanlığı Bilirkişilerinin Bilirkişilik Uygulamalarındaki Yetkinliğine Ait Bilgiler

\begin{tabular}{lcc}
\hline Değişken & Sayı (n) & Yüzde(\%) \\
\hline Yetkin olma durumu & & \\
\hline Evet, düşünüyorum & 40 & 61,54 \\
Hayır, düşünmüyorum & 25 & 38,46 \\
\hline Toplam & $\mathbf{6 5}$ & $\mathbf{1 0 0}$ \\
\hline
\end{tabular}

İş kazalarında bilirkişi olarak görev alan iş güvenliği uzmanlarının bilirkişilik alanında yetkin olup olmadığı ile ilgili soruya katılımcıların \%61,54’ü iş güvenliği uzmanlarının yetkin olduğunu, \%38,46’sı ise yetkin olmadığını belirtmiştir.

Tablo 20. İş Güvenliği Uzmanlarının Bilirkişilik Alanında Yetkinlik Kazanabilmesi İ̧̧in Gerekli Olan Hususlara Ait Bilgiler

\begin{tabular}{lcc}
\hline Değişken & Sayı (n: 65) & Yüzde (\%) \\
\hline Yetkinlik kazanma & & \\
\hline $\begin{array}{l}\text { Bilirkişilik konusundaki kanun ve yönetmelikler } \\
\text { ile bilirkişinin rol ve görevlerine dair bilgisinin } \\
\text { arttırılmasına }\end{array}$ & 39 & 60 \\
\hline $\begin{array}{l}\text { İ güvenliği konusunda mesleki bilgisini } \\
\text { arttırmasına }\end{array}$ & 45 & 69,23 \\
\hline $\begin{array}{l}\text { Etkili iletişim ve görüşme konusunda beceri } \\
\text { kazanmasına }\end{array}$ & 22 & 33,85 \\
\hline Mesleki branşlaşmanın olması & 40 & 61,54 \\
\hline \hline
\end{tabular}


İş güvenliği uzmanlarının bilirkişilik alanında yetkinlik kazanması için neye/nelere ihtiyaç duyulduğu ile ilgili çoktan seçmeli soruya katılımcıların \%69,23'ü iş güvenliği konusunda mesleki bilginin arttırılmasını, \%61,54'ü mesleki branşlaşmanın olması gerektiğini, \%60’1 bilirkişilik konusundaki kanun ve yönetmelikler ile bilirkişinin rol ve görevlerine dair bilgisinin arttırılmasını, $\% 33,85^{\prime} i$ ise etkili iletişim ve görüşme konusunda beceri kazanılmasını gerektiğini belirtmiştir.

Tablo 21. İ̧̧ Güvenliği Uzmanlı̆̆ Bilirkişilerine Göre Mesleki Branşlaşmanın Gerekli Olup Olmadiğına Ait Bilgiler

\begin{tabular}{lcc}
\hline Değişken & Sayı (n) & Yüzde(\%) \\
\hline Mesleki Branșlaşma & & \\
\hline Evet & 53 & 81,54 \\
Hayır & 12 & 18,46 \\
\hline Toplam & $\mathbf{6 5}$ & $\mathbf{1 0 0}$ \\
\hline
\end{tabular}

İş güvenliği uzmanlarının bilirkişilik alanında daha verimli çalışabilmeleri için bilirkişilik dosyalarında mesleki branşlaşma sağlanmasıyla ilgili soruya katılımcıların \%81,54'ü mesleki branşlaşma olması gerektiğini düşünürken, \%18,46's1 ise mesleki branşlaşmaya ihtiyaç olmadığını ifade etmiştir. Bazı iş güvenliği uzmanlığı bilirkişileri ise en azından madencilik, inşaat, kimya sektörleri gibi bazı çok tehlikeli meslek gruplarında branşlaşmaya gidilmesi gerektiğini belirtmiştir.

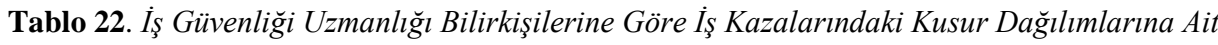
Bilgiler

\begin{tabular}{llll}
\hline Değişken & & Sayı (n:65) & Yüzde(\%) \\
\hline \multicolumn{2}{l}{ Kusur Dağılımı } & & \\
\hline \multicolumn{2}{l}{ Kazaların meydana gelme süreçleri } & 22 & 33,85 \\
\hline $\begin{array}{l}\text { Kazaların meydana } \\
\text { koşulların etkileri }\end{array}$ & gelme süreçlerindeki güvensiz & 45 & 69,23 \\
\hline $\begin{array}{l}\text { Kazaların meydana } \\
\text { davranışlar }\end{array}$ & gelme sürecindeki güvensiz & 50 & 76,92 \\
\hline \begin{tabular}{l} 
Kazaların meydana geldiği ortamın çevresel etkileri \\
\hline İş güvenliği mevzuatının tam olarak uygulanmayışı
\end{tabular} & 24 & 36,92 \\
\hline \hline
\end{tabular}

İş güvenliği uzmanlığı bilirkişisi olarak iş kazaları ve iş kazalarındaki kusur dağılımlarında en çok hangi durumların etkili olduğu ile ilgili çoktan seçmeli soruya, katılımcıların \%76,92'si kazaların meydana gelme sürecindeki güvensiz davranışlar, \% $\% 3,85$ 'i iş güvenliği mevzuatının tam olarak uygulanmayışı, \%69,23'ü kazaların meydana gelme süreçlerindeki güvensiz koşullar, \%36,92'si kazaların meydana geldiği ortamın çevresel etkileri, \%33,85'i ise kazaların meydana gelme süreçlerinin etkili olduğunu belirtmişlerdir.

Tablo 23. İş Güvenliği Uzmanlığı Bilirkişilerinin Görev Aldıkları Bilirkişilik Dosyalarında Mahkemeler Tarafindan Taktir Edilen Bilirkişilik Ücretlerinin Uygulamalarına Etkisine Ait Bilgiler

\begin{tabular}{lcc}
\hline Değişken & Sayı (n) & Yüzde(\%) \\
\hline Bilirkişilik ücretinin etkisi & & \\
\hline Evet etkilemektedir & 14 & 21,53 \\
\hline Hayır etkilememektedir & 47 & 72,31 \\
\hline Bir fikrim yok & 1 & 1,54 \\
\hline Bilirkişilik ücretini yeterli bulmaktayım & 3 & 4,62 \\
\hline Toplam & $\mathbf{6 5}$ & $\mathbf{1 0 0}$ \\
\hline \hline
\end{tabular}


İş Güvenliği Uzmanlığı Bilirkişileri Üzerine Bir Çalışma

Araştırmada bilirkişilik görevi kapsamında mahkeme tarafından takdir edilen bilirkişilik ücretlerinin bilirkişilik uygulamalarına etkisi ile ilgili soruya, katılımcıların \%72,31'ini etkilemediği, \%21,53'ünü etkilediği, \%4,62'si bilirkişilik ücretini yeterli bulduğu, \%1,54’ü ise konu ile ilgili hiçbir fikir belirtmemiştir.

Tablo 24. İ̧̧ Güvenliği Uzmanlığı Bilirkişilerinin Sahip Olduğu Belgelere Ait Bilgiler

\begin{tabular}{lcc}
\hline Değişken & Sayı (n) & Yüzde(\%) \\
\hline İş Güvenliği Uzmanlığı Belgeleri & & \\
\hline A Sınıfı İș Güvenliği Uzmanlık Belgesi & 37 & 56,92 \\
\hline B Sınıfi I̦s Güvenliği Uzmanlık Belgesi & 15 & 23,08 \\
\hline C Sınıfı İs Güvenliği Uzmanlık Belgesi & 13 & 20 \\
\hline Toplam & $\mathbf{6 5}$ & $\mathbf{1 0 0}$ \\
\hline
\end{tabular}

Araştırmada İş Sağlığı ve Güvenliği Genel Müdürlügünce verilmiş olan iş güvenliği uzmanlığı belgelerinin dağılımı incelendiğinde katılımcıların \%56,92'sinin A sınıfı iş güvenliği uzmanlığı belgesine, $\% 23,08$ 'inin $\mathrm{B}$ sınıfı iş güvenliği uzmanlığ \%20'sinin ise C sınıfı iş güvenliği uzmanlığı belgesine sahip olduğu belirlenmiştir.

\section{SONUÇ}

Türkiye'de yaşanan kazaların bir türlü önlenememesi, kazaların asıl kaynağının ne/neler olduğunun tam olarak kavranamamış olmasından kaynaklanabilir. 2003 yılında yürürlüğe giren 4857 sayılı İş Kanunu ve 2012 yılında yürürlüğe giren 6331 sayılı İş Sağlığı ve Güvenliği Kanunu iş kaza oranlarını düşürmeye yönelik önemli düzenlemeler içerse de istenen sonuç pek de alınabilmiş değildir. Yaşanmış kazaların analiz ve çözümlemeleri sebep sonuç ilişkisi dahilinde ele alınıp uzman kişilerce yorumlanarak alternatif önleyici tedbirler (tehlike kaynağında korunma, ikame, idari önlemler, güncel teknolojik uygulamalar, robotik sistemler vb.) geliştirilebilir. Endüstride uygulanan birçok koruyucu ve önleyici yöntemin, geçmişte yaşanmış iş kazaları sonucu ortaya çıktığı söylenebilir. Bu gelişime katkı sağlayan en önemli kaynaklardan biri de iş kazaları ile ilgili adli yargılamalar da adli makamlar tarafından görevlendirilen iş güvenliği uzmanlığı bilirkişi raporlarıdır.

Bilirkişi, adli yargılamalarda uzmanlık ve teknik konuları içeren hususlar ile ilgili soruşturma ve kovuşturma aşamasında adli makamlara yazılı veya sözlü destek veren kişilerdir. 2016 yılında kabul edilen Bilirkişilik Kanunu ve 2017 yılında yayımlanan Bilirkişilik Yönetmeliği, çağın koşullarına uygun ve daha nitelikli kişilerin bilirkişilik yapabilmesi doğrultusunda hazırlanmıştır.

Bu araştırmada Türkiye'de adli makamlarca görevlendirilen iş güvenliği uzmanlığı bilirkişilerinin, iş kazalarının dosya inceleme aşamasında maruz kaldıkları sorunlar belirlemeye ve bu sorunlara çözüm önerileri sunulmaya çalışılmıştır. Bu amaçla araştırmaya, çevrimiçi ankete yanıt veren 105 iş güvenliği uzmanlığı bilirkişileri arasından anketi eksiksiz yanıtlayan 65 iş güvenliği uzmanlığı bilirkişilerinin yanıtları dahil edilmiştir. Araştırmaya katılan iş güvenliği uzmanlığı bilirkişilerinin \%90,77'sinin bilirkişilik siciline kayıtlı olduğu, $\% 9,23$ 'ünün ise bilirkişilik siciline kaydı olmadığı belirlenmiştir. Katılımcılardan \%9,23'ünün bilirkişilik hukuki ehliyetinin bulunmamasına rağmen iş kazası adli yargılamalarında görev almaları sebebiyle araştırmaya dâhil edilmişlerdir.

Araştırmada iş güvenliği uzmanlığı bilirkişilerinin \%6,15'inin Bilirkişi Portalı UYAP üzerinden, \%1,54'ünün mahkeme tarafindan görev yaptığı kuruma görevlendirme yazılarak, \%92,31'inin mahkeme kalemi tarafindan telefon ile aranarak bilgi verilmek sureti ile görevlendirildikleri belirlenmiştir. Bilirkişi seçimi yargıca veya savcıya aittir. Ancak 
uygulamada bilirkişi seçimi mahkeme yazı işleri müdürleri tarafından yapıldığı ve bu seçim yapılırken bilirkişilerin temel ve alt uzmanlık alan ölçütüne göre değil "bildik-tanıdık olma" ölçütünün dikkate alındığı vurgulanmaktadır (TEPAV, 2016: 3). Bu nedenle bilirkişi atamalarının Ulusal Yargı Ağı Projesi- Bilirkişi Portalı üzerinden yapılması hedeflenmesine rağmen istenen sonuç pek de alınabilmiş değildir. Bu durum sistemin eşit, hakkaniyetli ve adil bir şekilde gerçekleşmesi açısından önemlidir. Hâlen bilirkişi görevlendirilmelerinin geleneksel yöntemlerle yapılması sistemin tam anlamıyla uygulanamadığının en belirgin göstergesidir (TMMOB, 2019: 27). UYAP sisteminin aktif bir şekilde kullanılması iş akışındaki belirsizlikleri ortadan kaldırabileceği gibi bilirkişi dosyalarının hızlı bir şekilde hazırlamasına da katkı sağlayacaktır.

Bilirkişilik Kanun ve Yönetmeliğinde iş güvenliği uzmanlığı bilirkişisi olarak başvuru yapabilmek için beş yıllık mesleki tecrübe şartı aranmaktadır. Fakat bazı iş güvenliği uzmanlığı bilirkişilerinin mevzuatın zorunlu tuttuğu beş yıllık deneyim şartını mesleki alanda taşıyıp iş güvenliği alanında taşımadığı tespit edilmiştir. Bu durum bilirkişi raporlarının eksik, hatalı veya yanlış hazırlanmasına neden olup adli makamları yanlış yönlendirmeye sebebiyet verebilir. Bu nedenle Bilirkişilik Kanunu ve Yönetmeliğinde yer alan bilirkişiliğe başvuru usul ve esasları kısmına iş güvenliği alanında da mesleki tecrübe ve deneyim hususu da eklenebilir.

Bilirkişi komisyonlarında görev alan bilirkişilerin hazırladıkları farklı raporların komisyon içinde bulunan diğer bilirkişiler tarafından imzalamaya zorlanabilmesi hazırlanan raporun şeffaflığını riske atabilmektedir. Bu çalışma sonucunda bazı iş güvenliği uzmanlığı bilirkişilerinin, taraf avukatları veya dava taraflarınca baskıya maruz kaldıkları belirlenmiştir. Bilirkişilerin, Bilirkişi Yönetmeliği'nin 58.md.'si gereği kamu görevlisi niteliği taşıması sebebiyle cezai ve hukuki sorumluluğu bulunmaktadır. Ancak bilirkişiye yönelik yukarıda bahsi geçen durumlar karşısındaki cezai yaptırım hususunun net olarak belirlenmemiş olması bilirkişilerin, bilirkişilikten çekilmeleri hatta kusurlu veya taraflı rapor hazırlamalarına neden olabilir. Bu nedenle kamu görevlisi niteliği taşıyan bilirkişilere yönelik muhtemel baskılara karşı daha caydırıcı yaptırımlar uygulanabilir.

Araştırmaya katılan iş güvenliği uzmanlığı bilirkişileri, Bilirkişilik Kanunu ve Yönetmeliği 1şığında mahkemeler tarafından 2018 yılı ocak ayından bu yana yapılan bilirkişilik görevlendirmelerinde, \%68,90’` bilirkişilerin bilirkişilik sicil kaydına bakıldığını, \%31,10’u ise bilirkişinin bilirkişilik siciline bakılmadığını ifade etmiştir. Adli makamlar sicile kayıtlı olmayan bilirkişileri görevlendirebilmektedir. Bilirkişi siciline kayıtlı olmayan kişiler tarafından hazırlanan bilirkişi raporları dava taraflarınca bir üst mahkemeye yapacakları itiraz ile verilen kararın bozulmasına sebep olabilir. Bu gibi durumlar dava süreçlerinin uzaması, maddi ve manevi kayıpların yaşanmasına neden olabilir. Bilirkişi raporlarının dava süreçlerinin karar aşamasında hakimleri etkileyebileceği göz önüne alınarak ve yeni mağduriyetlerin yaşanmasına yol açmaması için bilirkişi görevlendirmelerinde bilirkişilerin bilirkişi siciline kayıtlı olması zorunlu hale getirilebilir.

İş güvenliği uzmanlarının bilirkişilik alanında daha verimli çalışabilmeleri için katılımcıların \%81,54'ü bilirkişilik dosyalarında mesleki branşlaşmanın olması gerektiğini belirtirken, \%18,46'sı mesleki branşlaşmaya gerek olmadığ görüşünü belirtmiştir. 2017 y1lı iş kazası sonucu ölen işçilerin işkolları dağılımı incelendiğinde inşaat sektöründe 587, metal sektöründe 124, madencilik ve taş ocaklarında 86 ölümlü iş kazası gerçekleşmiştir (SHD, 2018: 11). Bahsi geçen sektörler ve benzeri çok tehlikeli sektörlerde bilirkişi görevlendirmeleri yapılırken temel ve alt uzmanlık alanlarının yanı sıra mesleki tecrübeleri ve iş güvenliği uzmanlığı alanındaki tecrübeleri de dikkate alınmalıdır. Madencilik sektöründe; gaz ve toz patlamaları, kavlak düşmesi, ocak suları vb. riskler bulunmaktadır. 
İnşaat sektöründe; yüksekten düşme, elektrik kazaları, sıkışma vb. riskler bulunurken, metal sektöründe; mekanik tehlikeler, ısı etkileri, gürültü vb. riskler bulunmaktadır. Riskler ve tehlikeler sektörel bazda değişkenlik gösterebilir. Bu nedenle iş kaza yargılamalarında bilirkişi görevlendirmeleri yapılırken mesleki branşlaşma göz önünde bulundurulmalıdır.

Araştırma genel olarak değerlendirildiğinde bu çalışmada iş güvenliği uzmanlarının bilirkişilik rolü ve karşılaştıkları sorunlar ele alınmıştır. Bilirkişilik uygulamalarının gün geçtikçe önem kazanması ve bu alanda yapılan çalışmaların azlığı nedeniyle bu çalışmanın literatüre önemli bir katkı sağlayacağı düşünülmektedir. Konu ile ilgili gelecekte çalışma yapmak isteyen araştırmacılara, bilirkişilik uygulamalarını sektörel açıdan incelemeleri, adli makamlar boyutunda incelemeleri ve yaşanmış örnek vakalar üzerinden incelemeleri önerilebilir.

\section{Kaynakça}

Atalı, M. (2016). 6754 Sayılı Bilirkişilik Kanunu ve Hukuki Konularda Bilirkişilik. Ankara Üniversitesi Hukuk Fakültesi Dergisi. 65(4). 3272

Biyıkcı, T. E. (2010). İş Sağlı̆̆l ve Güvenliğinin Sağlanmasında İş Güvenliği Uzmanlığı. Uludağ Üniversitesi. (Erişim: 19.02.2018).

Bilgin, Ö. ve Kılıç, M. S. (2018). Sosyal Hizmet Uzmanlarının Bilirkişilik Uygulamalarına Dair Bir Araştırma. Türkiye Sosyal Hizmet Araştırmaları Dergisi. 2(2).

Demircioğlu, M. (2006). Ulusal ve Uluslararası Hukukta İş Güvenliği Uzmanlığ 1 (İş Güvenliği Mühendisliği/ İş Güvenliği Teknisyenliği). İstanbul: Beta Yayınları.113.

Demircioğlu, A. ve Kalyon, A. Ş. (2013). İşverenin İş Kazalarından Doğan Sorumluluğu ve Kusur Hakkında Karar İncelemesi. Dokuz Eylül Üniversitesi Hukuk Fakültesi Dergisi. C.15. Özel Say1. 2014.

World Health Organization (1995). Global Strategy on Occupational Health For All: The Way to Health at Work, Geneva. 7-8.

International Labour Organization (ILO). World Labour Report. International Labour Office Geneva. 1993.

International Labour Organization (ILO) ve ÇSGB. (2017). İş Güvenliği Uzmanlarının Görev ve Sorumluluklarının Yürütülmesi ile ilgili Araştırma. Ankara. (Erişim: 11.01.2019).

Kılkış, İ. (2014). İş Sağlığı ve Güvenliği. Aysen Tokol-Yusuf Alper (Ed). Sosyal Politika (Bursa: Dora Yayıncilık). 252.

Kök, A.N.(2017). 6754 Sayılı Bilirkişilik Kanunu Neler Getirdi? Uyuşmazlık Mahkeme Dergisi. Say1.10. 447.
Mecek, H. (2011). Ceza Muhakemesinde Bilirkişilik (Yüksek Lisans Tezi). Selçuk Üniversitesi. Konya. (Erişim: 15.01.2019).

Öçal, M. ve Çiçek, Ö. (2017). Türkiye ve Avrupa Birliğinde İş Kazası Verilerinin Karşılaştırmalı Analizi. HAK-ISS Uluslararası Emek ve Toplum Dergisi. 6(16). (2017/3) ISSN: 2147-3668 - E-ISSN: 2587 - 103X. (Erişim:11.01.2019).

Polat, O. ve Güven, T. A. (2015). İngiliz, Amerika ve Türk Hukukunda Bilirkişilik Uygulamalarının Karşılaştırılması. TBB Dergisi. (119). 104.106.107

Ryan, W.(1989). Problems Facing The Safety Manager. Profess. Privatization and The Penal System: The American Experience and The Debate in Britain. 18-19.

Selek, H. S. (2016). İş Să̆lı̆̆ı ve Güvenliği Temel Konular. (1.Baskı). Ankara

Sosyal Haklar Derneği Emekçi Hakları Çalışma Grubu (2018). İş Sağlığı ve Güvenliği Raporu. [http://sosyalhaklardernegi.org/wp-content/ uploads/2018/12/SHD-\%C4\%B0\%C5\%9F\%C3 \%A7i-Sa\%C4\%9Fl\%C4\%B1\%C4\%9F\%C4\% B1-ve-\%C4\%B0\%C5\%9F-G\%C3\%BCvenli \%C4\%9Fi-Raporu_13.12.2018-2.pdf]._(Erişim: 31.10.2019).

TMMOB Bilirkişilik Alanında Yaşanan Sorunlar ve Çözüm Önerileri Raporu. 2019. Türkiye Ekonomi Politikaları Araştırma Vakfi. (2016). Türkiye'de Bilirkişilik Sorunlar ve Çözüm Önerileri. TEPAV Hukuk Çalışma Merkezi 2016. [https://www.tepav.org.trupload /files/1454940891-9.Turkiye_de_Bilirkisilik_. Sorunlar_ve _Cozum_Onerileri.pdf]. (Erişim: 21.03.2019). 
Ulukapı, Ö. (2001). Bilirkişi Raporu ve Bilirkişi Raporunun Delil Olarak Değeri. Selçuk Üniversitesi Hukuk Fakültesi Dergisi. 9(3-4) 206-207.

Yücel, A. R. Bilirkişilik Kurumu ve Uygulamadaki Sorunlar. Türkiye Mühendislik Haberleri. 447-2008/1. [http://www.imo.org.tr/ resimler/ekutuphane/pdf/10799.pdf]. (Erişim: 15.01.2019)

6754 Sayılı Bilirkişilik Kanunu. (2016. 24 Mayıs). Resmî Gazete. S. 29898. [http:// www.resmigazete.gov.tr/eskiler/2016/11/20161 124-1..htm]. (Erişim:15.01.2019)

5510 No'lu Sosyal Sigortalar ve Genel Sağlik Sigortas1 Kanunu (2006, 31 May1s). Resmî Gazete. S. 26200. [https://www.mevzuat. gov.tr/MevzuatMetin/1.5.5510.pdf]. (Erişim: 11.01.2019).

6331 Sayılı İş Sağlığı ve Güvenliği Kanunu (2012, 20 Haziran). Resmî Gazete. S.28339. [http://www.mevzuat.gov.tr/MevzuatMetin/1.5. 6331.pdf]. ( Erişim:11.01.2019).

Bilirkişilik Yönetmeliği (2017). Resmî Gazete. S.30143. (Erişim:13.02.2019).

Bilirkişilik Temel ve Alt Uzmanlık Alanlarına Göre Aranan Nitelikler. 2018 yılı 2. Dönem Bilirkişilik Başvurularına İlişkin Duyuru. [http://bilirkisilik.adalet.gov.tr/dokumanlar/ 2018/mart/EK-2\%20\%20ARANAN\%20N\%C4 $\%$ B0TEL\%C4\%B0KLER.pdf]. Erişim: 13.02.2019).

İş Güvenliği Uzmanlarının Görev, Yetki, Sorumluluk ve Eğitimleri Hakkında Yönetmelik. (2012, 29 Aralık). Resmî Gazete. S. 28512. [http://www.mevzuat.gov.tr/Metin.Aspx ?MevzuatKod=7.5.16923\&MevzuatIliski=0]. (Erişim: 11.01.2019).

Bilirkişilik Daire Başkanlığı. Bölge Bilirkişilik Listeleri. 2018-2019. [http://bilirkisilik.adalet. gov.tr/sayfalar/bilirkisilisteleri.html]. (Erişim:02.01.2019). 